\title{
RECENT CATTLE EGRET BREEDING RECORDS FOR THE LAST MOUNTAIN LAKE AREA, SK
}

KERRY HECKER, Canadian Wildlife Service, Environment Canada, P.O. Box 280, Simpson, SK, S0G 4M0 E-mail: <kerry.hecker@ec.gc.ca>, and PHILIP S. TAYLOR, Canadian Wildlife Service, Environment Canada, 115 Perimeter Road, Saskatoon, SK, S7N 0X4, E-mail: <phil.taylor@ec.gc.ca>

During the summer of 2005, Cattle Egrets successfully bred at Stalwart National Wildlife Area (NWA) near Stalwart, SK. This was the third breeding record for Cattle Egrets in Saskatchewan; the two earlier records were of single pairs at Old Wives' Lake Migratory Bird Sanctuary in 1981, and Eyebrow Lake in 1994.6,7,8 Subsequent to 2005, Cattle Egret nests were found in Saskatchewan at Middle Quill and Goose Lakes, ${ }^{2}$ and in a marsh north of Last Mountain Lake National Wildlife Area but the 2005 record remains the only nesting record for Stalwart NWA. This record was mentioned briefly in previous articles. ${ }^{2,4}$ Here we provide details of that event and additional observations of this species' recent nesting efforts in the area.

Stalwart NWA (Figure 1) consists of a large marsh just east of Highway \#2 adjacent to the hamlet of Stalwart (51 $40 \mathrm{~N} ; 10528 \mathrm{~W}$ ). The area is an important stopover for migrating waterfowl and shorebirds, as well as a highly productive breeding marsh for many water dependent birds including colonial nesting species like Eared Grebe, Black-crowned Night-Heron, and Franklin's Gull.

\section{5}

On 2 June 2005, D. Duncan (Environment Canada, Canadian Wildlife Service, Edmonton) visited Stalwart NWA and saw one small, white, heron-like bird, carrying a strand of vegetation in its beak, fly up from the east-west grid road that runs through the north part of the Stalwart NWA. He tentatively identified it as a Cattle Egret and reported to the CWS staff at Last Mountain Lake National Wildlife Area (LMLNWA) that it might be nesting.

Subsequent visits by the second author (PST), and later by both of us, found the egrets flying to and from, and landing in, an area of reeds and grass, comprised primarily of bulrush Scirpus $s p$. and Common Reed Grass Phragmites communis. Some of these birds were carrying nesting material in their bills. On 7 June 2005, we saw two adult Cattle Egrets flying from northwest of the Stalwart grid road to land in the same reeds. On 9 June 2005, PST observed five adults in the same area, and two flew from the reeds with strong, purposeful flight to the north-west, presumably to forage. This area of reeds interspersed with shallow open water was also used by Eared Grebes, 


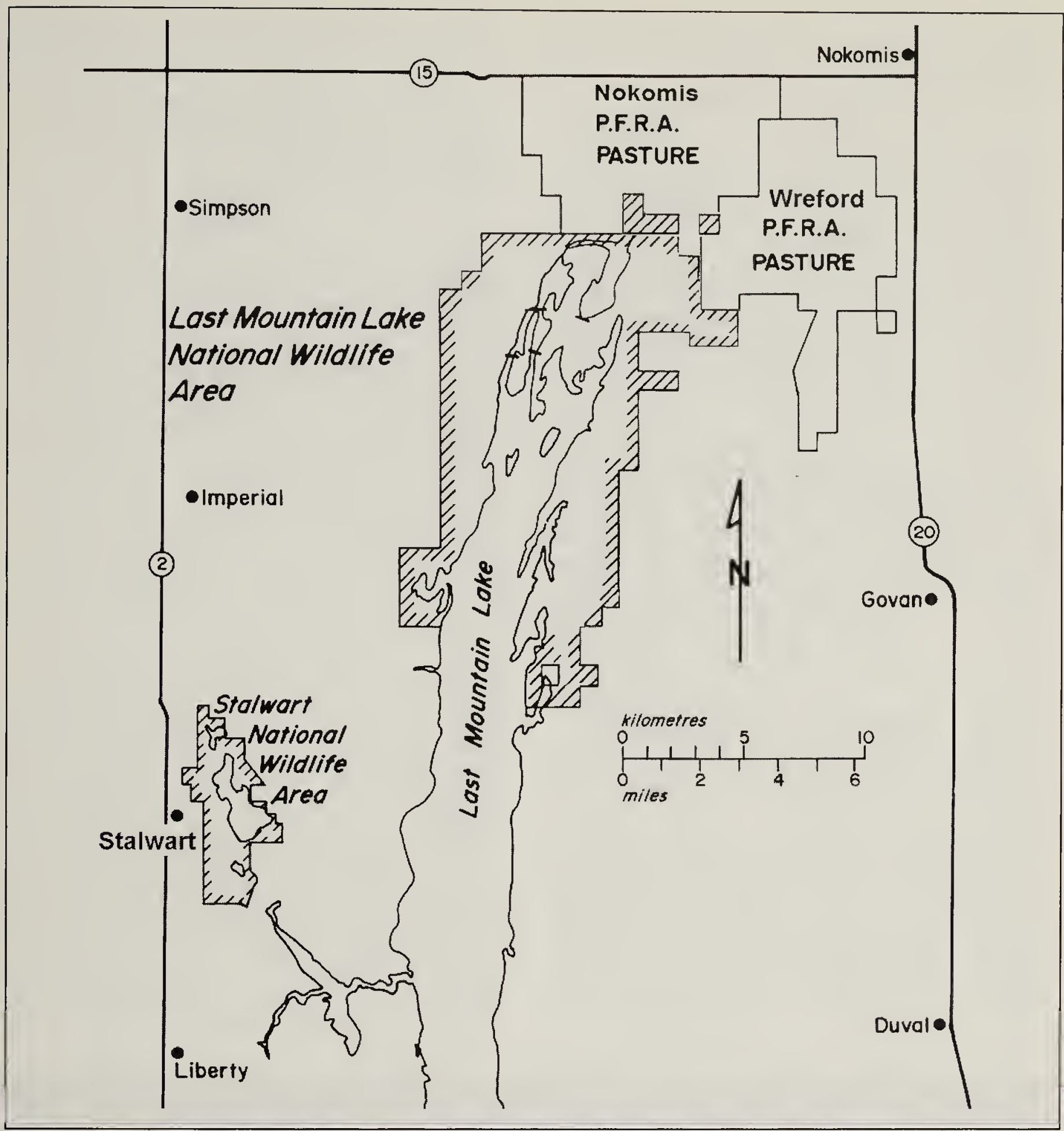

Figure 1. Stalwart NWA and Last Mountain Lake NWA.

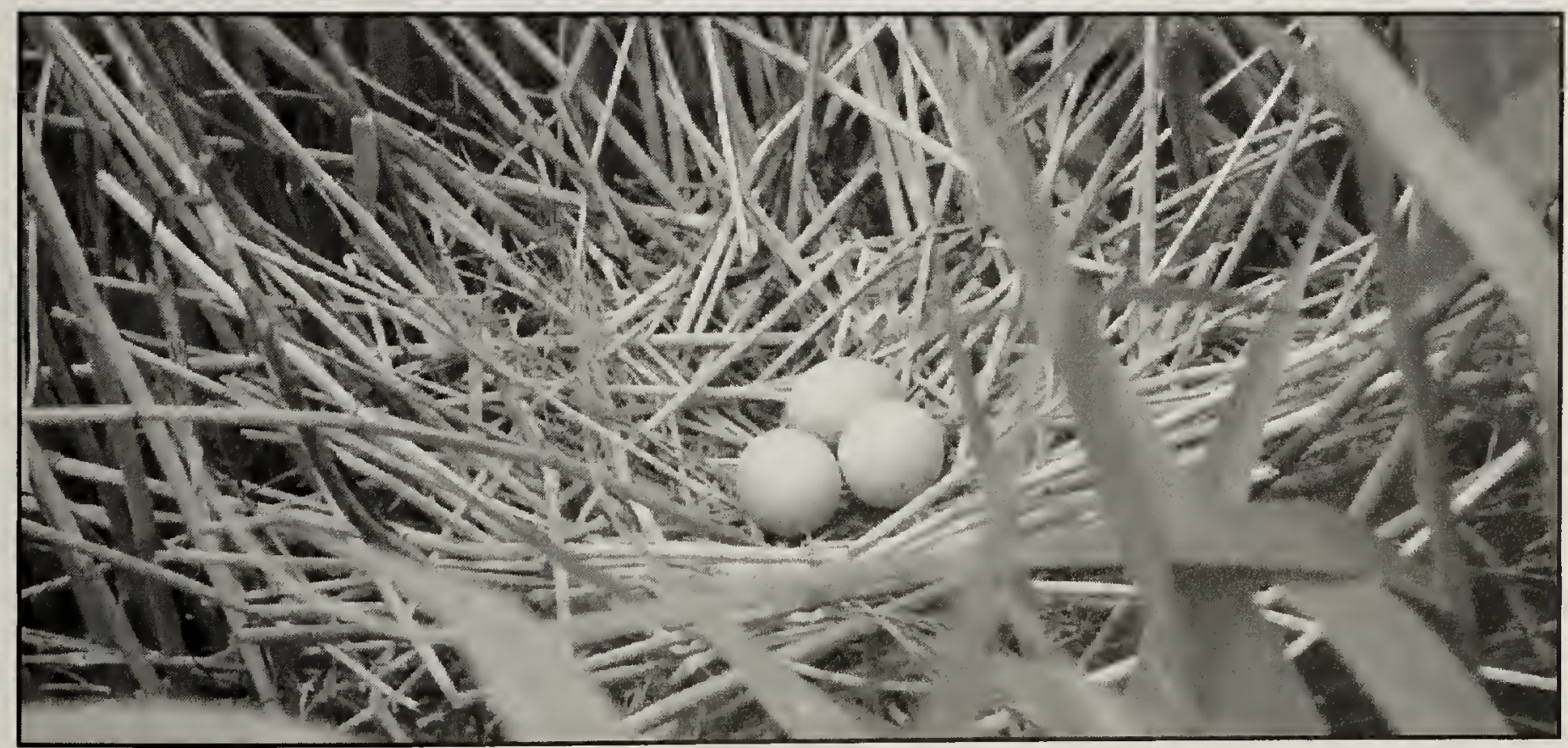

Figure 3. Cattle Egret nest with eggs

Kerry Hecker, Environment Canada - Canadian Wildlife Service 
Black-crowned Night-Herons and Franklin's Gulls for nesting.

On 11 June 2005, we conducted an aerial census of colonial waterbirds in some NWAs and Migratory Bird Sanctuaries in Saskatchewan, including Stalwart NWA. While flying over the Stalwart marsh, we counted a minimum of four potential egret nests and took photographs.

On 16 June, we made a brief survey of the Franklin's Gull colony by canoe to evaluate and enumerate species nesting in the area. At this time, we observed seven Cattle Egrets in the marsh - unmistakably adults in breeding plumage (Figure 2, see inside back cover) - and numerous Blackcrowned Night-Herons. We found a number of nests in the marsh. Of particular interest were those constructed of both dead and live reeds, plucked and woven into standing dead and green reeds. The nests were elevated approximately $40 \mathrm{~cm}$ above the surface of the water, and were up to 20 $\mathrm{cm}$ deep, with a firm rounded cup containing between two and four eggs. (Figure 3) This description is consistent with that of Black-crowned Night-Heron nests, ${ }^{3}$ and similar to Cattle Egret nests. ${ }^{5,10}$

While visiting the nests, we could distinguish two distinct types of eggs in nests, although the nest structures were all similar. We used these observed differences in eggs to decide which nests belonged to which species. One type of egg, surmised to be a Cattle Egret egg, was approximately $4 \mathrm{~cm}$ long by $3 \mathrm{~cm}$ wide, distinctly elliptical, and pale blue. (Figure 4) The other, surmised to belong to Black-crowned Night-Herons, was a bit larger, $4.5 \mathrm{~cm}$ long by $3 \mathrm{~cm}$ wide, pointed at one end and a slightly darker blue. These were verified later using descriptions in Davis, Harrison and Telfair. $^{3,5,10}$ During our visit, which we kept as brief as possible, we found three Cattle Egret nests with four, four, and three eggs, and five Black-crowned Night-Heron nests, each with four eggs. Not wishing to disturb the birds further, we then continued our gull

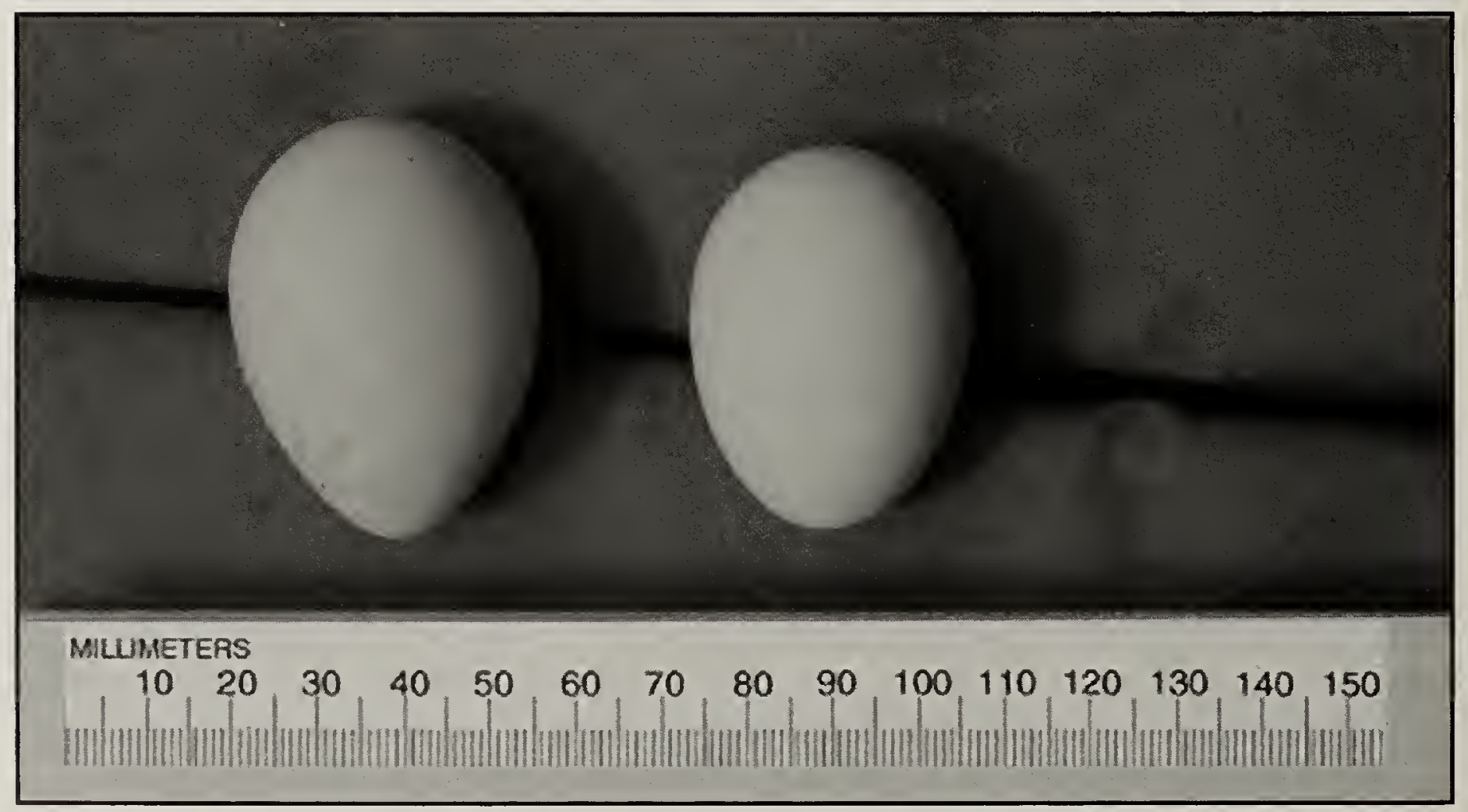

Figure 4. Comparison of smaller, more rounded and lighter blue Cattle Egret egg (right), and larger, more pointed, and darker blue Black-crowned NightHeron egg (left). Kerry Hecker, Environment Canada - Canadian Wildlife Service 
survey and left the marsh shortly thereafter.

We do not believe that we found all the egret and night-heron nests present in the colony during our brief visits by aircraft and canoe. In the canoe, we only visited the periphery of the colony and did not search deeper into the reed bed or in several sites where adult egrets were seen from the air. Observations of adult egrets flying to and from the nesting area suggest there may have been as many as seven or eight pairs in total. The number of night-heron nests in this colony was estimated to be between 25 and 40 pairs.

We, along with Al Smith and Ross Dickson (RDD), continued to record egret sightings through autumn. The sightings of both adult and young-ofyear birds in the Stalwart area were plentiful until the end of September, and the last sighting was on 18 October 2005.4 On 9 December 2005, the authors went to Stalwart NWA to count old nest structures in the colony. While the specific reed and grass beds containing the nests were found, no nest platforms or other evidence of the bird colony were present.

\section{6}

High water levels and a large local muskrat population in the fall and winter of 2005-2006 resulted in the dying back of a number of the bulrush and Common Reed Grass beds at Stalwart NWA in 2006, including those supporting the Franklin's Gull, Cattle Egret and Black-crowned Night-Heron colonies. Eared Grebes and Franklin's Gulls initially returned to these areas but did not stay to nest in any numbers.

On 17 May, between 1600h-1640h, PST saw seven Cattle Egrets in breeding plumage perched in one of the remaining bulrush stands at the 2005 Stalwart NWA breeding colony. One pair copulated. During this time, five additional egrets in breeding plumage flew south-west over the marsh nearby but did not land. On 31 May, PST saw no egrets in the bulrush stand, but observed at least two egrets in a dense stand of Common Reed Grass $100 \mathrm{~m}$ west of the old colony site. Black-crowned Night-Herons established a small colony ( $<25$ pairs) in this reed grass stand in 2006. On June 12 , PST saw a single egret in a different reed grass stand south-east of the 2005 colony site. There were no further egret sightings and no indication of successful breeding at Stalwart NWA in 2006.

Cattle Egrets were locally common at LMLNWA in 2006, approximately 14 $\mathrm{km}$ north-east of Stalwart NWA. As described in Dickson et al $2007^{4}$, the Cattle Egrets at LMLNWA showed behaviour indicative of nesting at a specific site in June and July 2006; during August and September, a flock of Cattle Egrets foraged with a cattle herd near Highway 15 north of the NWA headquarters. The last sighting was 19 October 2006.

\section{7}

The first Cattle Egret sighting in 2007 was of a single bird on 29 April, $5 \mathrm{~km}$ west of Last Mountain Lake NWA Headquarters by RDD. Visits to the 2005 and 2006 breeding colony locations found no evidence of nesting egrets; these visits occurred on 18 May 2007 by Beyersbergen, ${ }^{2}$ and on 1, 15 and 31 May, and 11, 18 and 29 June 2007 by one or both of the authors. The water levels at Stalwart NWA in spring 2007 were within the normal variation for the spring runoff period. On 11 July 2007, a mixed colony of Cattle Egrets and Black-crowned Night-Herons was discovered by PST $15 \mathrm{~km}$ north of LML 


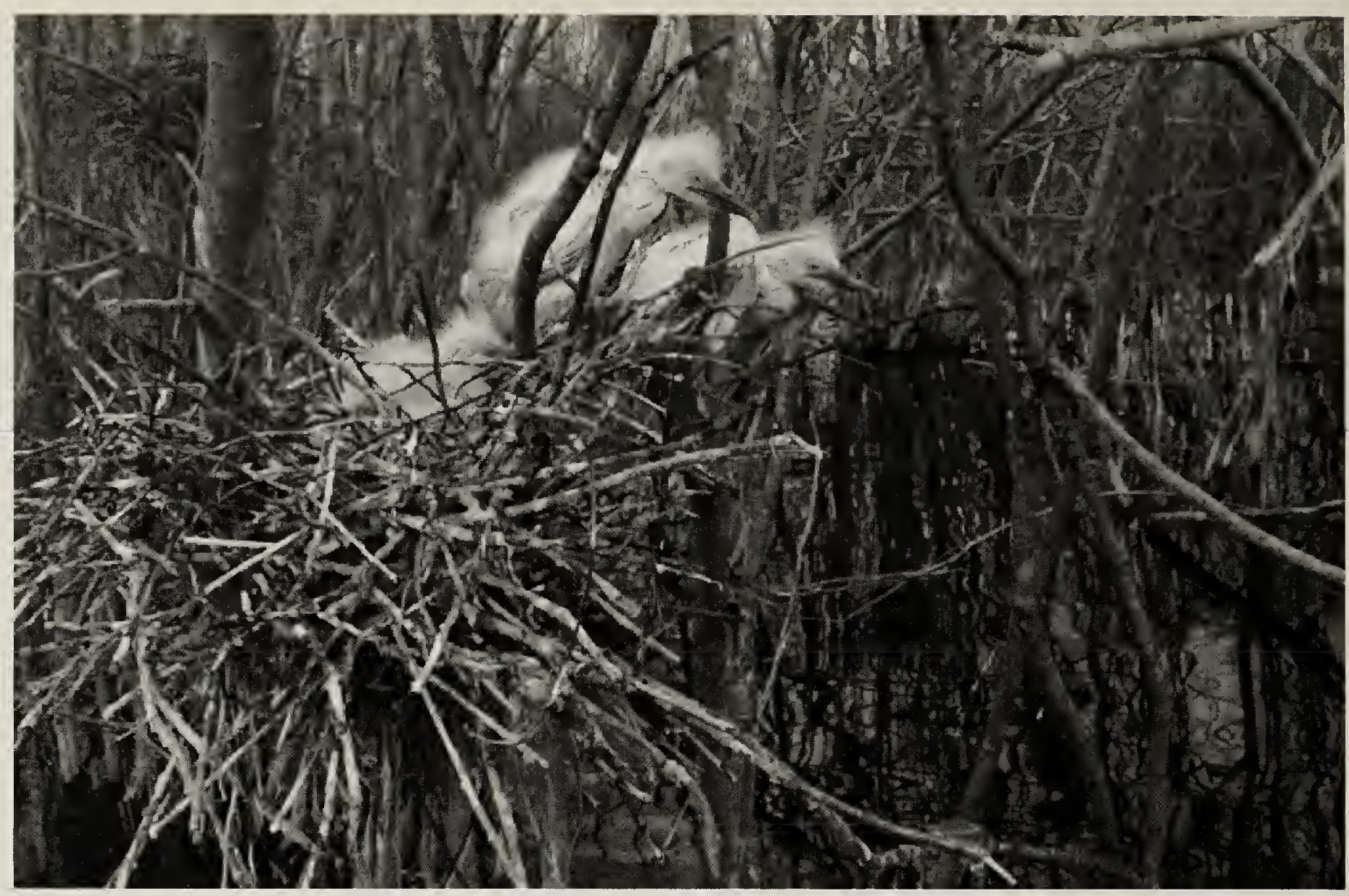

Figure 5. Three Cattle Egret chicks on a stick nest in flooded willows on 14 August 2007. Joseph Kotlar, Environment Canada

NWA and documented with photographs. Unlike the previous two years, this egret and night-heron colony was established in flooded willows (Salix spp.) 3-5 m tall, bordering an open wetland. Nest structures were built of sticks among the willow branches, often more than one nest to a one willow and some only $1 \mathrm{~m}$ above the water surface. Some unoccupied nest structures were in disrepair and could have been built in a previous year. Stains on the willow trunks indicated that water levels had been at least 25 $\mathrm{cm}$ higher in the recent past, very likely including the record high spring flood event of 2006. RDD and Joseph Kotlar visited this colony on 14 August to determine success of the breeding effort and noted that all 10 active egret nests that they located were $1.25-3 \mathrm{~m}$ above the water surface in August (Figure 5). This position appeared to allow adults to land on the platform or on nearby branches and to leave quickly.
These nests were quite different in materials, structure and height than the nests found at Stalwart NWA in 2005, however they were more typical of nests described for this species. ${ }^{10}$ This nesting habitat is similar to our first recorded sightings of Cattle Egrets that seemed indicative of breeding behaviour, which were made in the high-water years of the mid- 1990s. ${ }^{4}$ On 26 July 1996, PST and M. Tataryn observed several adult Cattle Egrets perched in and flying around a live willow stand 3-4 $\mathrm{m}$ tall, surrounded by nesting American White Pelicans and Double-crested Cormorants on an island in Last Mountain Lake Migratory Bird Sanctuary. ${ }^{9}$

During the 14 August 2007 visit, RDD counted 16 egrets capable of flight some are assumed to be fledglings plus one large chick that stayed at the top of a willow. In addition, he found seven active nest platforms; three with downy chicks crouching in the bowl, 
and the rest with feathered chicks standing on them or clinging to branches near them. A rapid count indicated these broods were 2, 3, 3, 4, 4,4 and 5 chicks. One of the 3 -chick nests also contained an egg. On 15 September, only a single large chick capable of flight remained at the colony location. No adults were seen. All observations thereafter in 2007 were of adults and immature egrets feeding with cattle near Highway 15. Throughout the summer these small white egrets were seen regularly foraging with cattle herds along Highway 15, north of Last Mountain Lake National Wildlife Area. Four fledglings and one adult seen on 1 October were the last Cattle Egrets recorded in 2007.

These results suggest that two nesting efforts were made by Cattle Egrets at this colony in 2007, from either a later influx of breeders to the colony or a renesting effort following earlier losses. Whether such later nesting is typical of this species in our area is not known. Possibly, this was a renesting attempt from birds that had been unsuccessful here or elsewhere. For example, Middle Quill Lake is only 85 km away, and on 13 July 2007 six nests with recently abandoned Cattle Egret eggs were discovered; the adults were not located on that visit or a subsequent visit on 17 July 2007 by Beyersbergen. ${ }^{2}$

Cattle Egrets may have been breeding in the area for more years than those we have documented. Our observations indicate adult egrets are surprisingly restricted in their movements during the breeding season. They can show a strong fidelity to foraging with one or two herds of cattle, within 2 to $6 \mathrm{~km}$ of the nesting colony, often taking direct flights between the two locations. Pure white egrets in flight can be difficult to see depending on the sky and light conditions so may be missed even by careful observers. Egrets are most visible when feeding with cattle, often perching on the backs of standing or resting animals. Other cattle herds pasturing closer to the colony seemed not to be visited regularly if at all. Unless egret nesting or feeding sites are in areas frequently visited by observers, they can be missed.

Notably, the same year Cattle Egrets bred successfully at Stalwart NWA was the first documented breeding for the species in Manitoba. ${ }^{1}$ Cattle Egrets appear to be settling in as regular breeders in and around Last Mountain Lake National Wildlife Area. It will be interesting to observe whether they persist through wet and dry years, and how they adjust their colony location in the process. The Cattle Egret's affinity for nesting with other colonial species, particularly Black-crowned NightHerons in our area, suggests they have opportunities to expand their nesting in prairie Canada.

\section{Acknowledgements}

We would like to thank the Canadian Wildlife Service staff and birdwatchers who reported sightings, behaviour, dates, and numbers. These include (in alphabetical order) Ross Dickson, Dave Duncan, Joseph Kotlar, Dan Neiman, Dan Sawatzky, AI Smith, Lowell Strauss, Cindy Swoboda, Mark Tataryn and Rob Wapple. Thanks also to Ron Bazin, Ross Dickson, and Al Smith for providing helpful comments on the initial draft of this paper.

1. BAZIN, R. 2006. First Documented Breeding Records of Cattle Egrets in Manitoba. Blue Jay 64(3): 126-130.

2. BEYERSBERGEN, G. W. 2008. Cattle Egrets and nests found during Franklin's Gull surveys in Saskatchewan in 2006 and 2007. Blue Jay 66(2): 70-73. 
3. DAVIS, W. E., Jr. 1993. Black-crowned NightHeron (Nycticorax nycticorax). In The Birds of North America, No. 74 (A. Poole and F. Gill, Eds.). Philadelphia: The Academy of Natural Sciences; Washington, D.C.: The American Ornithologists' Union.

4. DICKSON, R. D., A. R. SMITH, and P. S. TAYLOR. 2007. Status of Wading Birds (Ardeids and Ibises) at the north end of Last Mountain Lake in 2006. Blue Jay 65(2): 67-77.

5. HARRISON, Colin. 1984. A Field Guide to the Nests, Eggs, and Nestlings of North American Birds. Collins Publishers, Don Mills, ON.

6. RONEY, K. 1982. Cattle Egret nesting record for Saskatchewan. Blue Jay 40:163-164.
7. ROY, J.F. 1996. Birds of the Elbow. Saskatchewan Natural History Society Special Publication No. 21, Regina.. SK

8. SMITH, A.R. 1996. Atlas of Saskatchewan Birds. Nature Saskatchewan, Special Publication No. 22. Regina, SK.

9. TATARYN, M. 1996. Colonial Bird Surveys at Last Mountain Lake National Wildlife Area, Saskatchewan, Canada. Summer Survey Report for LML NWA - Environment Canada - Canadian Wildlife Service.

10. TELFAIR, R. C. II. 1994. Cattle Egret (Bubulcus ibis). In The Birds of North America, No. 113 (A. Poole and F. Gill, Eds.). Philadelphia: The Academy of Natural Sciences; Washington, D.C.: The American Ornithologists' Union.

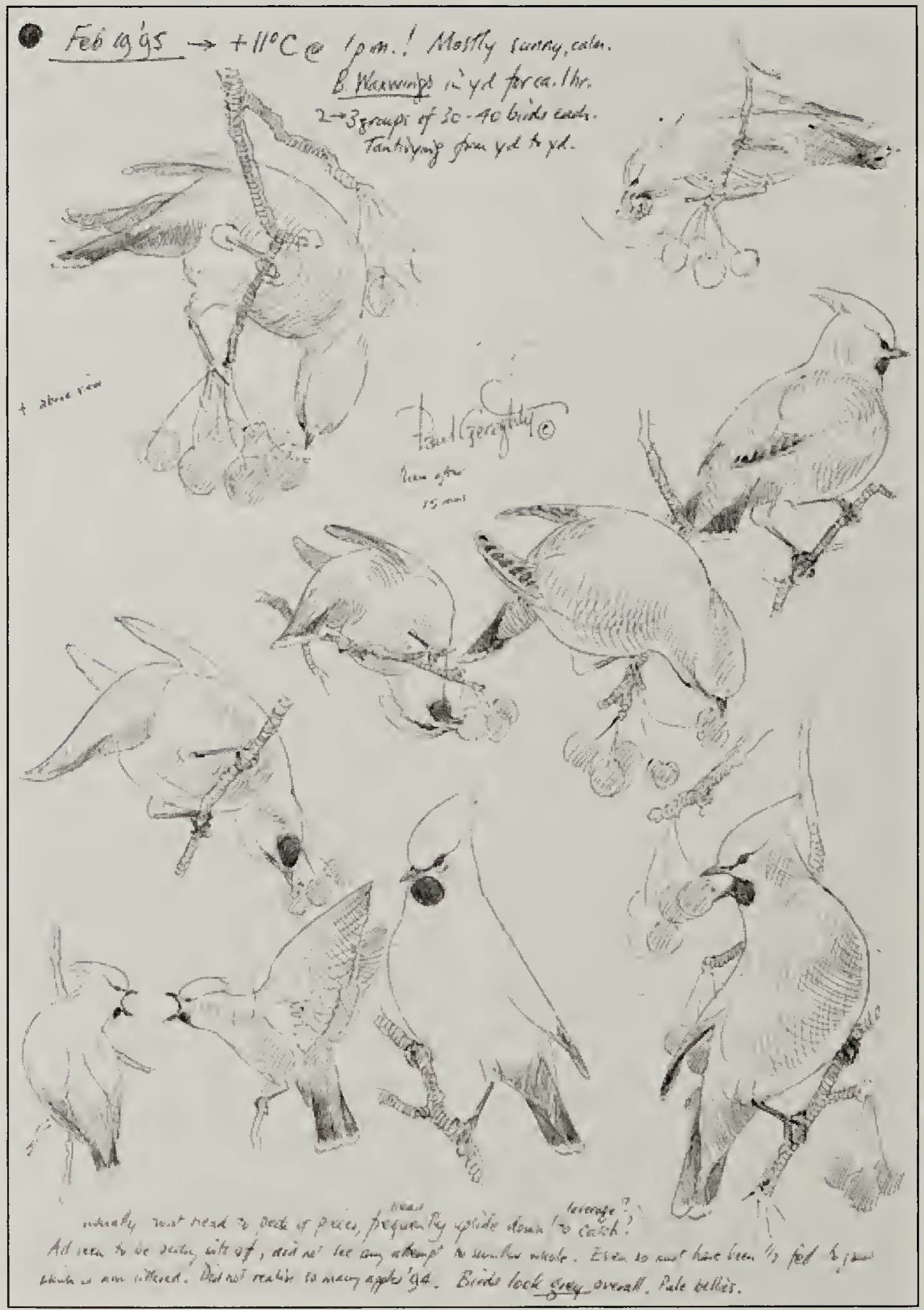

